\title{
Childhood Acute Myeloid Leukemia with Minimal Differentiation
}

National Cancer Institute

\section{Source}

National Cancer Institute. Childhood Acute Myeloid Leukemia with Minimal

Differentiation. NCI Thesaurus. Code C8304.

An acute myeloid leukemia with minimal differentiation occurring in children. 